\title{
Morphotectonic control of the Białka drainage basin (Central Carpathians): Insights from DEM and morphometric analysis.
}

\author{
Bartosz Wołosiewicz
}

Department of Fundamental Geology, Faculty of Earth Sciences, University of Silesia in Katowice, ul. Będzińska 60, 41-200 Sosnowiec, Poland,

Correspondence: bartek.wolosiewicz@gmail.com

Received: $18^{\text {th }}$ January, 2016

Accepted: $13^{\text {th }}$ June, 2016

\begin{abstract}
The Białka river valley is directly related to a deep NNW-SSE oriented fault zone. According to the results of previous morphometric analyses, the Białka drainage basin is one of the most tectonically active zones in the Central Carpathians. It is also located within an area of high seismic activity.

In this study Digital Elevation Model (DEM) based, morphometric analyses were used to investigate the morphotectonic conditions of the watershed. The results reveal the relationships between the main tectonic feature and the landforms within the research area. The lineaments, as obtained from the classified aspect map, seem to coincide with the orientation of the main structures as well as the trends revealed by the theoretical RiedelSkempton shear model. Base-level and isolong maps support the conclusion that the Białka and Biały Dunajec fault zones exert a strong influence on the morphology of the adjacent area.
\end{abstract}

Key words: morphometry, morphotectonics, Carpathians, remote sensing

\section{Introduction}

The Białka river (sk. Biela Voda) is located in the Central Western Carpathians along the Polish-Slovakian border (Fig.1) and is a tributary of the Dunajec river. Its source is located high within the Tatra Mts. The valley of the river is founded on the Białka Fault zone (Jurewicz, 2005), which is the major geological structure responsible for the morphology of the adjacent area. Regional morphometric studies have demonstrated that the Białka watershed is one of the most tectonically active zones in the Central Carpathians (Baumgart-Kotarba, 1983, Ozimkowski, 2002; Zuchiewicz, 2010; Wołosiewicz and Chybiorz, 2015). Two major earthquakes that took place here in 1995
(Guterch, 2009; Zuchiewicz, 2010) also support this thesis.

This paper is an attempt to present some new facts on the morphology of the Białka drainage basin in the context of the tectonic architecture of the research area. The methods used are DEM based, morphometric analysis as well as lineament aalysis, which allow for the quantitative investigation of the relationships between tectonic structures and geomorphological features.

Similar methods have already been used for various mountainous and upland locations in Poland (e.g. Zuchiewicz, 1981, 1999, 2010; Brzezińska-Wójcik et al., 2010; Badura et al., 2007) and many similar terrains around the world (e.g. Bull, 1977, 1978, 2007; Bull and McFadden, 1977). 


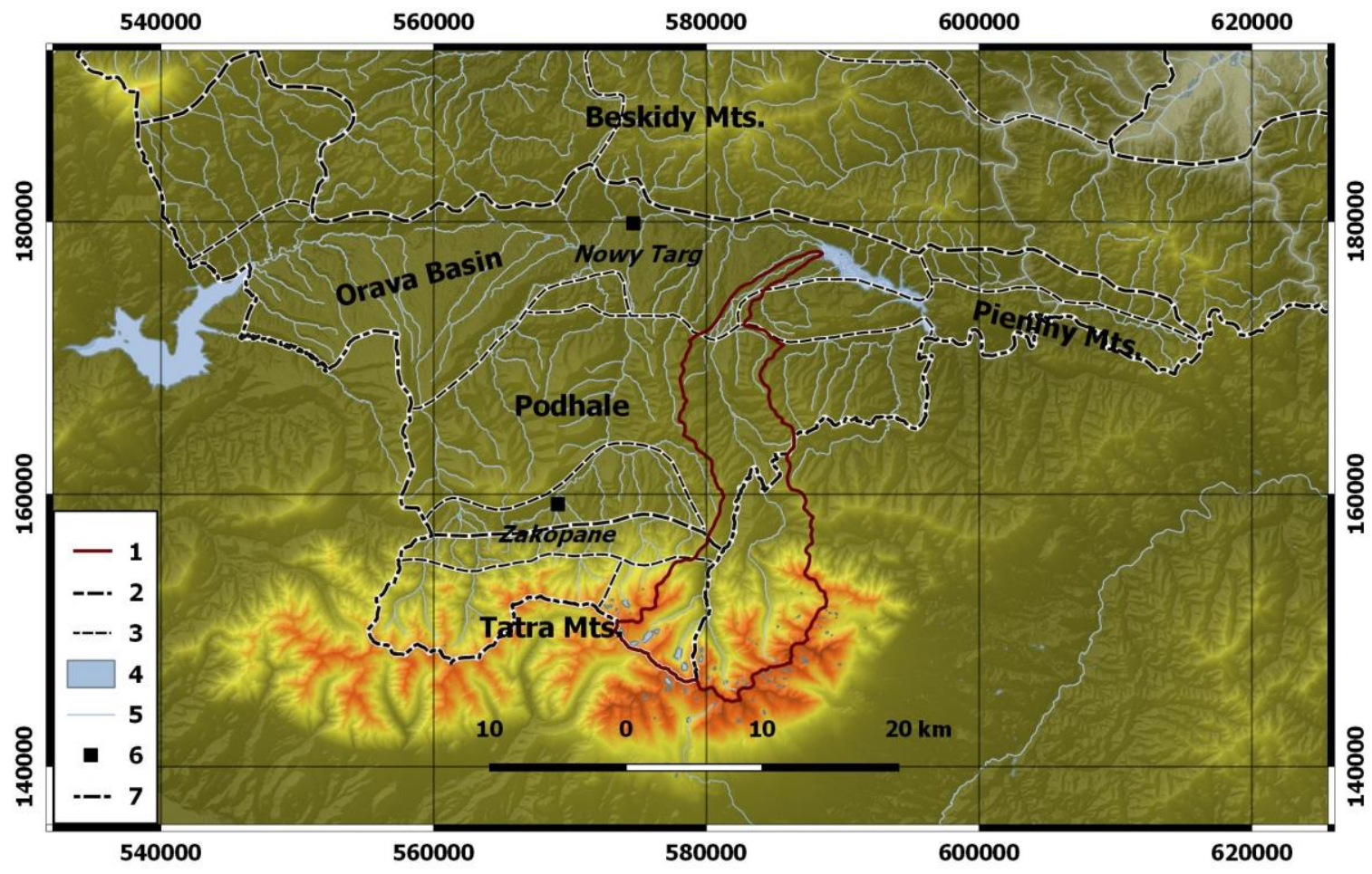

Fig.1. Localization of the Białka drainage basin: 1. Białka drainage basin; 2. macroregions (Starkel, 1972 ); 3. mesoregions (Starkel, 1972); 4. lakes; 5. rivers; 6. cities; 7. state boundary.

\section{Study area}

\section{Geological setting}

The Carpathians stretch from Austria to the Iron Gate in Romania. Their complex lithological and tectonic architecture (Żelaźniewicz et al., 2011) is a result of the dynamic geological evolution of the area (Jurewicz, 2005).

The Białka drainage basin is located within the internal area of Western Carpathians, known as the Inner Carpathians (Internides) or the Central Carpathians (Książkiewicz, 1977). The Inner Carpathians are the oldest orogenic zone within the range. They were folded during the Late Cretaceous and they are in tectonic contact with the Outer (Flysch) Carpathians across the Pieniny Klippen Belt.

The Białka drainage basin can be divided into three main tectonic units: Tatra Mts. to the
South; Podhale in its central part; and a small part of the Orava Basin to the North. Moreover, within the Tatra Mts. several sub-units can be distinguished. The igneous and metamorphic rocks of the Tatra crystalline core occur in the southern part of the research area (Fig.2). It comprises a fragment of the exhumated Inner Carpathian Paleozoic basement. On the crystalline basement, autochthonous Mesozoic sedimentary rocks were deposited. They are overlain by several allochtonous thrust sheets and small nappes: High Tatric Nappes, Križna Nappe and Choč Nappe (e.g. Jurewicz, 2005). All these units are discordantly covered with a transgressive succession of the Central Carpathian Palaeogene Basin, mainly flysch sediments exposed in the Podhale Trough synclinorium, located between the massif of the Tatra Mountains and the Pieniny Klippen Belt (Marshalko, 1970). 


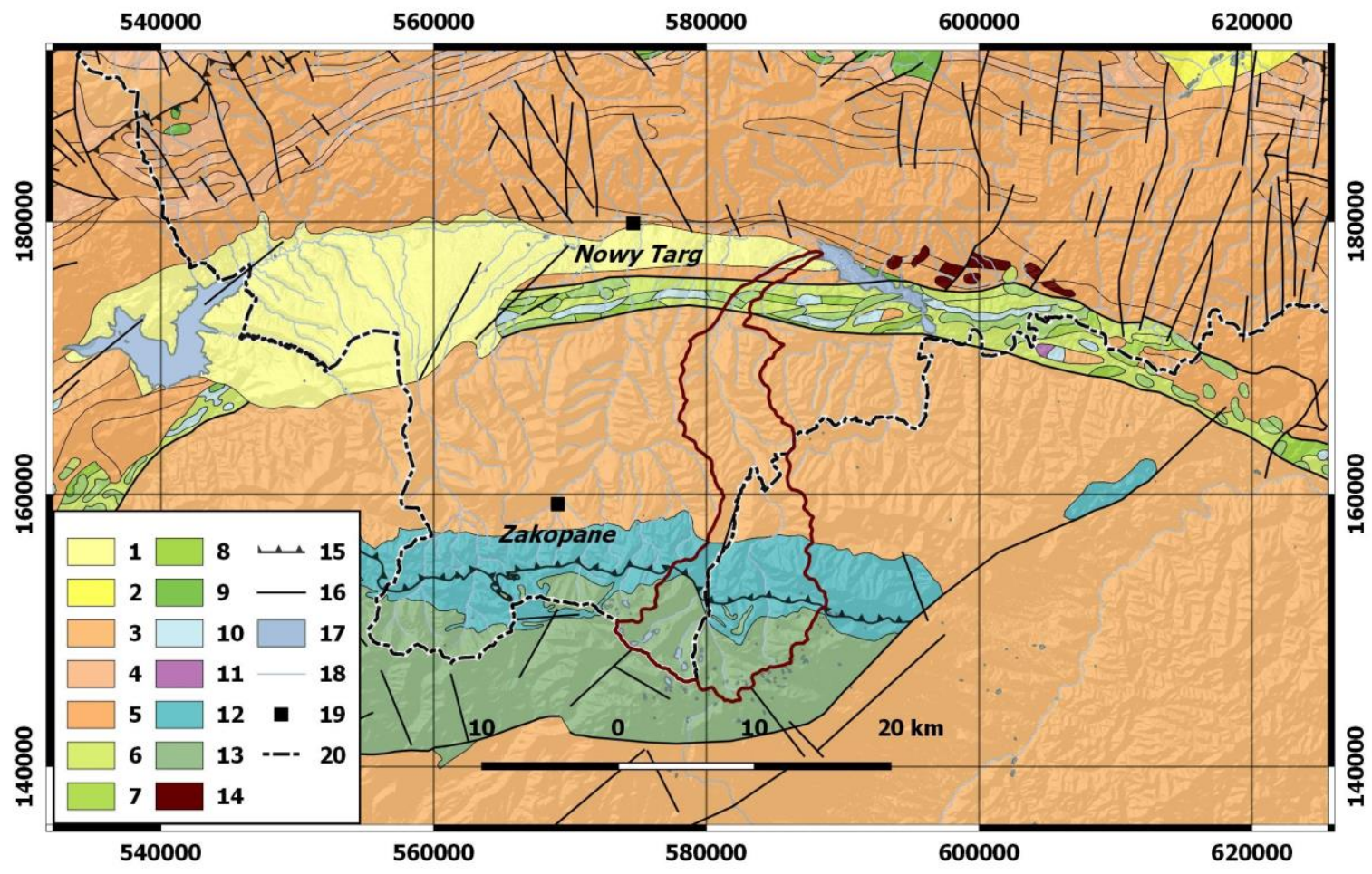

Fig.2. Geological sketch map (after: Fusan et al. 1967; Bac-Moszaszwili et al., 1979; Kawecka and Zając et al., 1989; Jurewicz, 2005, Marks et al., 2005) Geological map: 1. Pliocene-Miocene - clays with lignite, sands, gravels - continental deposits; 2. Badenian-Karpatian - clays intercalated with lignite and sands, locally with limestone and marl intercalations - continental deposits; 3. Oligocene-Eocene - Central Carpathian flysch; 4. Middle and Lower Paleogene - claystones, mudstones, subordinately sandstones; 5. Oligocene-Middle Eocene - sandstones, mainly thick bedded, mudstones, claystones subordinately marls and intercalations of shale-sandstones flysch; 6 . Upper Senonian - sandstones, conglomerates, subordinately claystones - Jarmuta Formation (Pieniny Klippen Belt); 7. Barremian-Toarcian - claystones, marls, limestones, subordinately radiolarites (Czorsztyn subunit of Pieniny Klippen Belt); 8. Upper Cretaceous - claystones, variegated marls; 9. Turonian - sandstones, claystones, marls, conglomerates; 10. Kimmeridgian-Sinemurian - claystones, sandstones, marls, limestones, radiolarites (Magura unit); 11. Ladinian-Anisian - limestones and dolomites (Haligovce subunit of the Pieniny Klippen Belt); 12. Mesozoic - limestones and dolomites (Tatra Mts. nappes); 13. Paleozoic - gneiss, para-gneiss, amphibolites, granites, shales (metamorphic-igneous basement of Tatra Mts.); 14. andesites; 15. thrusts; 16. faults; 17. lakes; 18. rivers; 19. cities; 20. state boundary.

In addition to the Peri-Pieniny Fault, the other major tectonic structures within the region are: Sub-Tatra Fault; Ružbachy Fault; the thrusts related to the Carpathian nappes; and a series of NNW-SSE oriented, dextral faults: Czarny Dunajec Fault, Biały Dunajec Fault, Białka Fault, Rieka Fault and Dunajec Fault (Fig.3). They were activated as a consequence of Miocene oblique subduction and subsequent collision of the North-European continental crust with the Central Carpathian Block (Jurewicz, 2005).

\section{Geomorphological setting}

The Białka river is a tributary of the Dunajec river, which flows along the Polish-Slovakian border (Fig.1). The river basin covers an area of 224.88 square kilometers and according to the Hydrographic Map of Poland (IMGW, 2007) it is a 6th order watershed. Most of the streams, especially the major ones, are meridional. A NE-SW orientations is characteristic for minor streams (Fig.4). 
The morphology of the river basin in the area of the Tatra Mts. has been strongly influenced by glaciers (Klimaszewski, 1978, 1988) and many of the landforms were ultimately shaped by at least four major Pleistocene glaciation events (BaumgartKotarba, 1983; Lindner et al., 2003). However, it is tectonics that is considered the crucial factor affecting the fluvial geomorphology of these mountainous regions (Hantke and Scheidegger, 1999).

\section{Materials and methods}

\section{Morphometry}

Geomorphometry is the science of quantitative land surface analysis (Pike, 2000, 2002). Some geometric and morphometric parameters of the Białka drainage basin were calculated, during a previous study of the neotectonic activity of the Pieniny Seismic Region (Wołosiewicz and Chybiorz, 2015). They were as follows (Tab.1):
Geometric coefficients:

- Area (A; Horton, 1945);

- Length (L) of the watershed defined as the length of the line segment between the mouth of the basin and the point on its perimeter, passing through the beginning of the longest watercourse (Horton, 1945);

- Mean (W) width of the basin (BrzezińskaWójcik et al., 2010);

- Perimeter (P; Smith, 1950).

Morphometric coefficients:

- Elongation Ratio (Re), which is calculated as a ratio of the circle diameter, the area of which is equal to the area of a drainage basin, to the maximum basin length (Schumm, 1954; Eagleson, 1970; Brzezińska-Wójcik et al., 2010). The drainage basins tend to show $\mathrm{Re}$ values ranging from 0 to 0.50 for tectonically active areas, from 0.50 to 0.75 for slightly active areas and values $>0.75$ for inactive settings (Bull and McFadden, 1977);

Tab.1. Geometric and morphometric parameters describing drainage basins (modified from Wołosiewicz and Chybiorz, 2015): Re - elongation ratio; $\mathrm{Rk}$ - circulatory ratio; $\mathrm{Rf}$ - form ratio; $\mathrm{k}$ - lemniscate coefficient; PSR Pieniny Seismic Region.

\begin{tabular}{|c|c|c|c|c|c|}
\hline Parameter & Symbol & Formula & References & $\begin{array}{c}\text { Values calculated } \\
\text { for Białka Drainage } \\
\text { Basin (Wołosiewicz } \\
\text { and Chybiorz, } \\
\text { 2015) }\end{array}$ & $\begin{array}{c}\text { Mean values in } \\
\text { the PSR area } \\
\text { (Wołosiewicz } \\
\text { and Chybiorz, } \\
\text { 2015) }\end{array}$ \\
\hline Total area & $\begin{array}{c}\mathrm{A} \\
{\left[\mathrm{km}^{2}\right]}\end{array}$ & - & Horton (1945) & 224.88 & 18.96 \\
\hline Length & $\mathrm{L}[\mathrm{km}]$ & - & Horton (1945) & 33.48 & 6.23 \\
\hline Perimeter & $\mathrm{P}[\mathrm{km}]$ & - & Smith (1950) & 100.41 & 17.21 \\
\hline Average width & $\mathrm{W}[\mathrm{km}]$ & $\mathrm{A} / \mathrm{L}$ & $\begin{array}{l}\text { Brzezińska-Wójcik et } \\
\text { al. (2010a) }\end{array}$ & 6.72 & 1.99 \\
\hline Elongation ratio & $\operatorname{Re}$ & $\begin{array}{c}2(\mathrm{~A} / \pi)^{0.5} \\
\mathrm{~L}\end{array}$ & Schumm (1954) & 0.51 & 0.64 \\
\hline Circulatory ratio & $\mathrm{Rk}$ & 4лА/ $\mathrm{P}^{2}$ & Miller (1953) & 0.28 & 0.55 \\
\hline Form ratio & $\mathrm{Rf}$ & $\mathrm{A} / \mathrm{L}^{2}$ & Horton (1945) & 0.20 & 0.33 \\
\hline $\begin{array}{l}\text { Lemniscate } \\
\text { coefficient }\end{array}$ & $\mathrm{k}$ & лL²/4A & Chorley (1971) & 3.91 & 2.85 \\
\hline
\end{tabular}




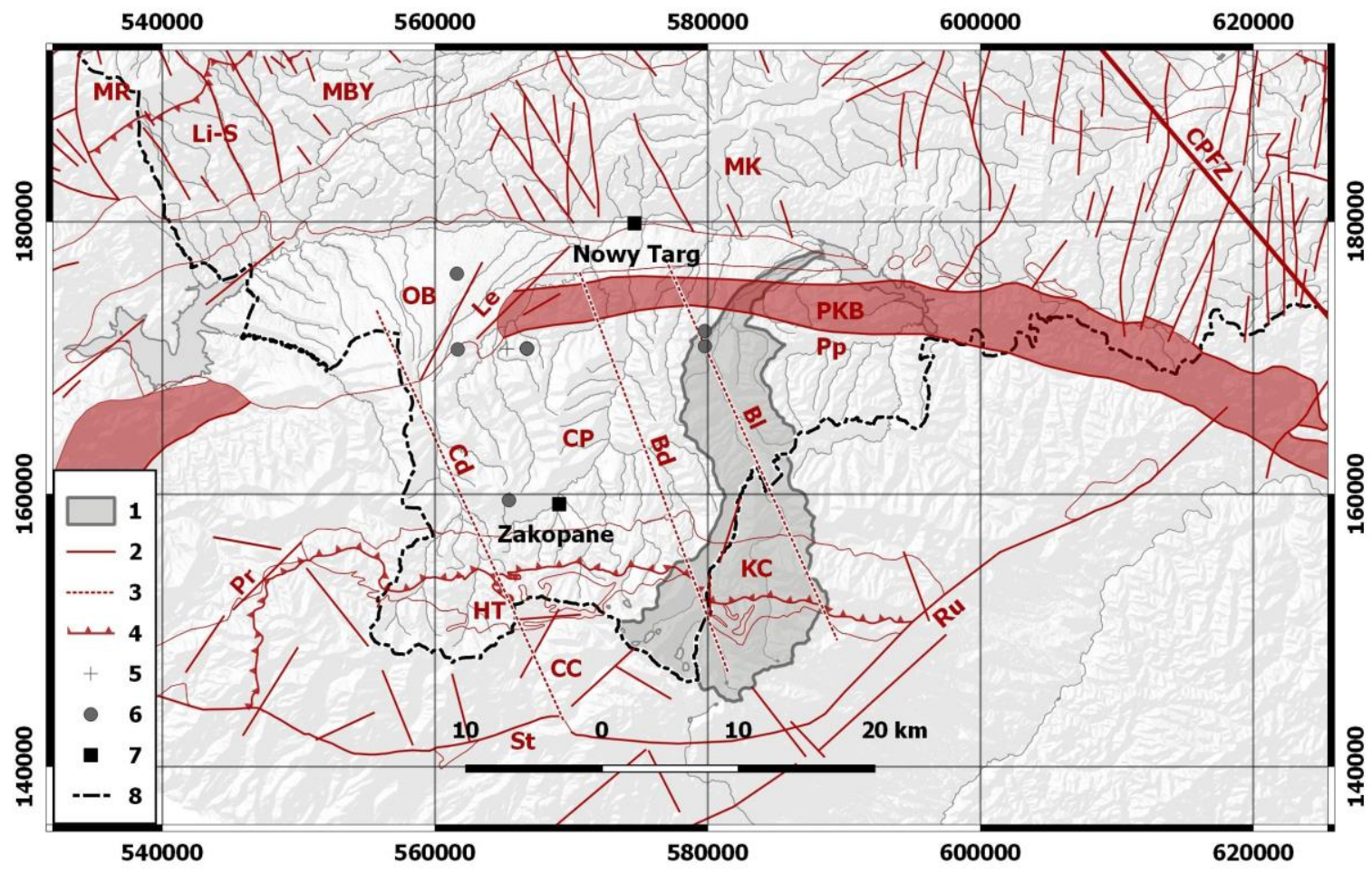

Fig.3. Tectonic sketch map (after: Fusan et al. 1967; Bac-Moszaszwili et al., 1979; Kawecka and Zając et al., 1989; Jurewicz, 2005): 1. Białka drainage basin; 2. faults; 3. supposed deep fault zones; 4. thrusts; 5. supposed earthquakes epicenters; 6. reliable earthquakes epicenters; 7. cities; 8 . state boundary. Main tectonic units: CC Crystalline Core of Tatra Mts., HT - High Tatric Nappe, KC - Križna and Choč Nappe, CP - Central Carpathian Paleogen, PKB - Pieniny Klippen Belt, OB - Oravic Basin, Magura Nape: MK - Krynica Unit, MB - Bystrica Unit, MR - Rača and Siary Unit; DU - Dukla Unit, SK - Skole Unit; G - Grybów Unit; SL - Silesian Nappe; Main faults: St - Sub-Tatra Fault, PP - Peri-Pieniny Fault, Cd - Czarny Dunajec Fault, Bd - Biały Dunajec Fault, Bl - Białka Fault, (Jurewicz, 2005), Ru - Ružbachy Fault, Pr-Le - Prošec-Lepetnica Fault, Li-S - Lipnica-Sylec Fault (Baumgart-Kotarba, 1998); CPFZ - Cracow-Prešov Fault Zone (Żaba, 1995).

- Circulatory Ratio (Rk) compares the area of the watershed to the circle whose perimeter is equal to that of the basin. Drainage basins can be considered as tectonically active, slightly active and inactive, according to $\mathrm{Rk}$ values ranging from $<0.50$, through $0.50-0.75$, to $>0.75$, respectively (Brzezińska-Wójcik et al., 2010);

- The Form Ratio Rf (Horton 1945) compares the outline of the drainage basin to a rectangle (Brzezińska-Wójcik et al., 2010a). It is significant that the value of the $\mathrm{Rf}$ coefficient decreases with the increase of the basin area (Eagleson, 1970; Gregory and Walling, 1973). Watersheds are classified as tectonically active, slightly active and inactive, according to Rk values ranging from $<0.25$, through $0.25-0.50$, to $>0.50$, respectively (Brzezińska-Wójcik et al., 2010);

- The Lemniscate Coefficient (k; Chorley, 1971) values calculated for the studied area increase with increasing tectonic activity of the watershed. For the studied area of the Pieniny Seismic Region (Wołosiewicz and Chybiorz, 2015), drainage basins characterized by $\mathrm{k}$ values $>3$ can be considered as tectonically active; $2-3$ as slightly active and $<2.0$ as tectonically in active. 

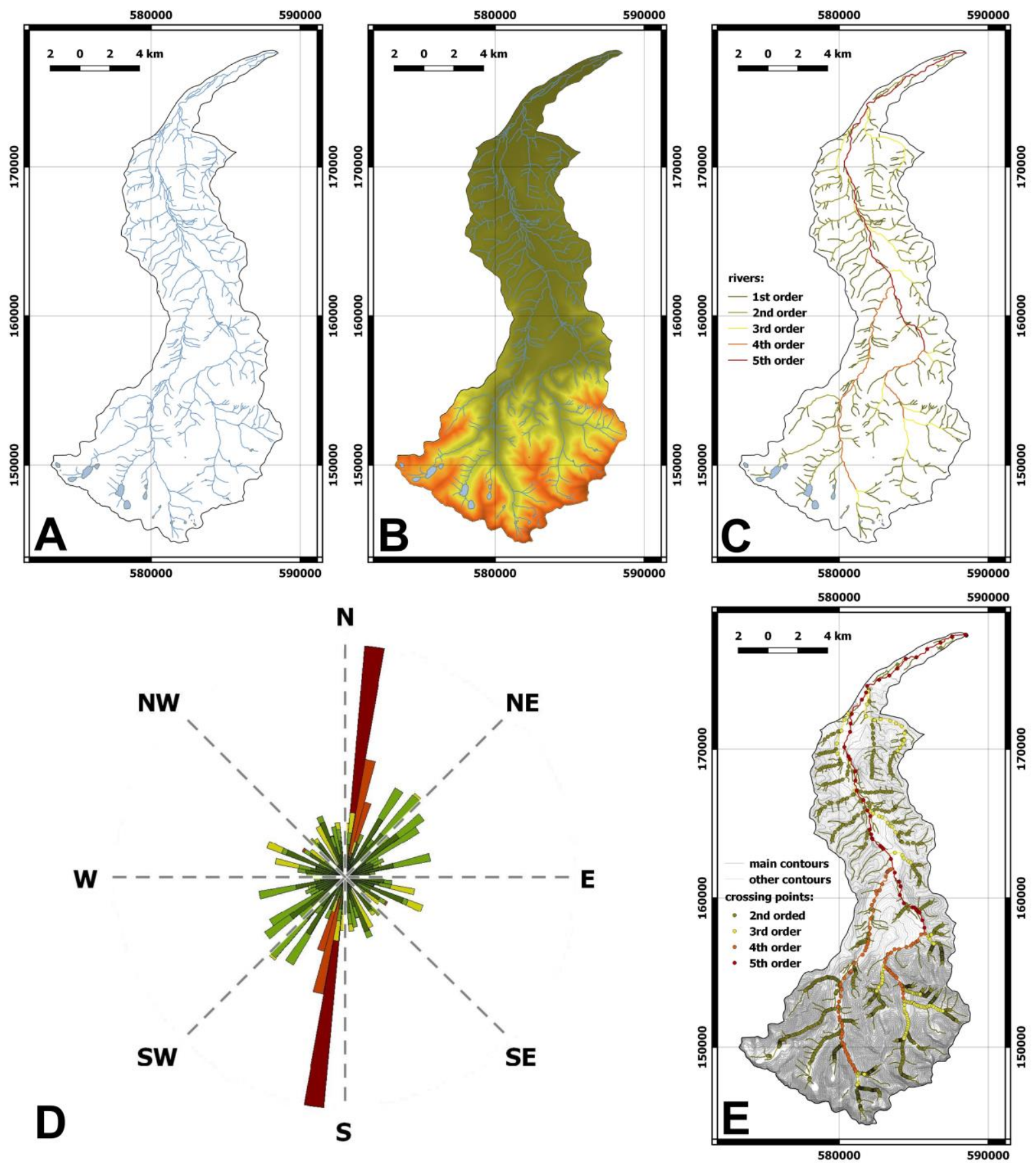

Fig.4. Hydrological analysis. A. Drainage system map; B. Drainage system map on the background of DEM; C. Rivers classified according to Strahler method; D. Rose diagram of rivers length. Colors according to Fig.4C; E. Streams and elevation isolines crossing points.

\section{Digital Elevation Model}

The Digital Elevation Model (DEM) of the study area, as well as all the derived data presented in this study are based on the Digital Terrain Elevation Database level 2 (DTED2; Fig.5). The DTED 2 was constructed by the
Geographic Survey of the Polish Army in 1999. The model was developed based on a topographic map 1:50 000 in the WGS-84 coordinate system (courtesy of ZGW WOGiT 2000). The DTED 2 data were filtered with the simple filter to reduce the noise and systematic errors (Jordan, 2003), achieving a smooth raster 
image. The difference is visible between the raw (Fig.5A) and filtered (Fig.5B) as well as in the histogram (Fig.5D). A classified hypsometric map (Fig.5C) was developed to visualize the topographic features of the research area.
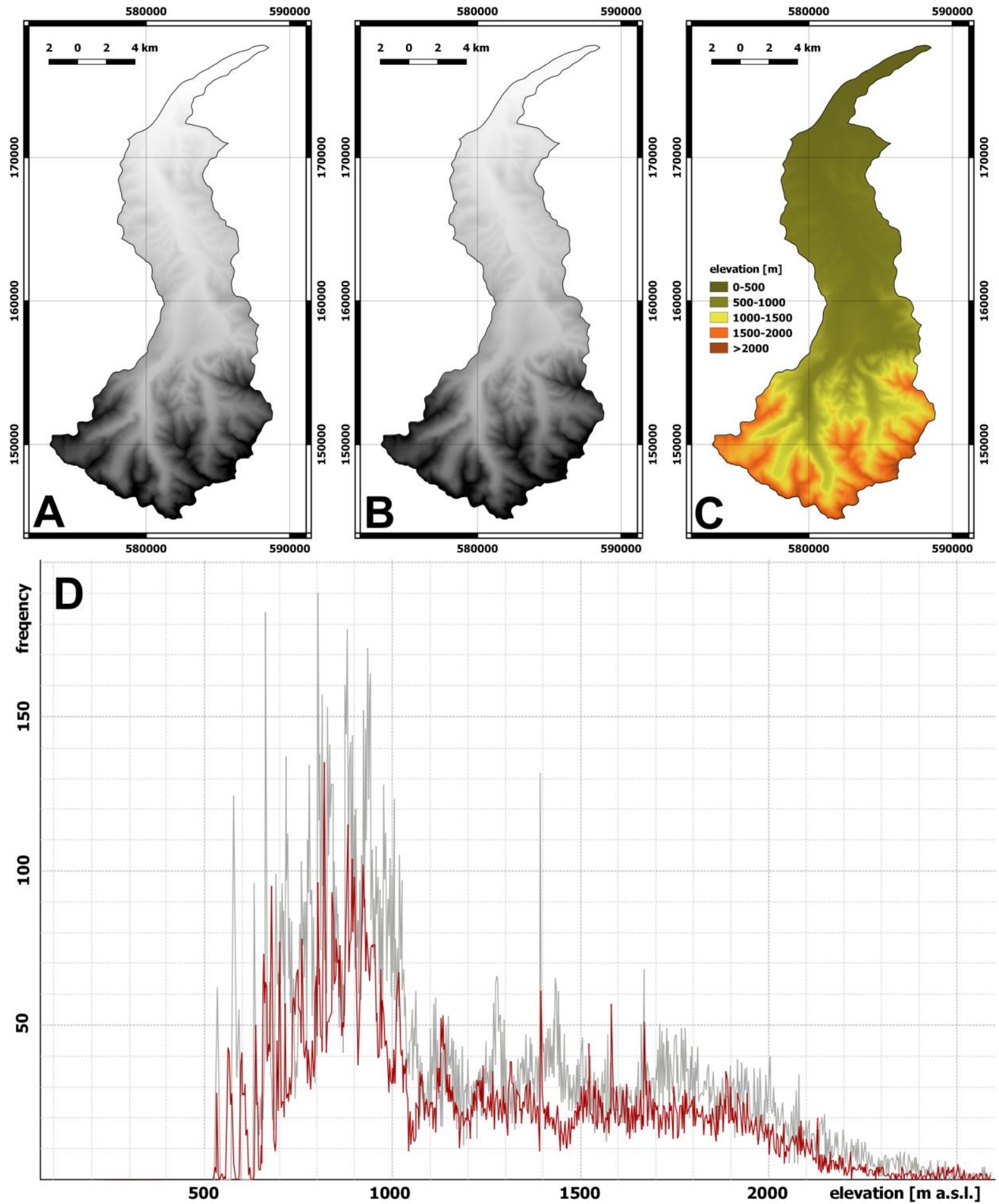

Fig.5. Elevation analysis. A. Digital elevation model (based on DTED 2); B. Digital elevation model filtered image; C. Classified hypsometric map; D. DEM histogram: grey line - raw data; red line - filtered data. 
Slope Inclination Map

The slope inclination map of the Białka drainage basin (Fig.6A) was developed using the Slope tool from the Terrain Analysis toolbar of the Quantum GIS 2.10 software package. It was also filtered with the simple filter (fig. 6B). The classes were distinguished according to Klimaszewski (1963; 1978; Fig.6C; Tab.2)
Tab.2. Slope inclination classes according to Klimaszewski $(1963,1987)$.

\begin{tabular}{cc}
\hline Slope inclination & Slope Classification \\
\hline $0^{\circ}-2^{\circ}$ & plains \\
$2^{\circ}-4^{\circ}$ & slightly inclined slopes \\
$4^{\circ}-9^{\circ}$ & moderately inclined slopes \\
$9^{\circ}-19^{\circ}$ & strongly inclined slopes \\
$19^{\circ}-45^{\circ}$ & steep slopes \\
$45^{\circ}-65^{\circ}$ & very steep slopes \\
$>65^{\circ}$ & crags \\
\hline
\end{tabular}
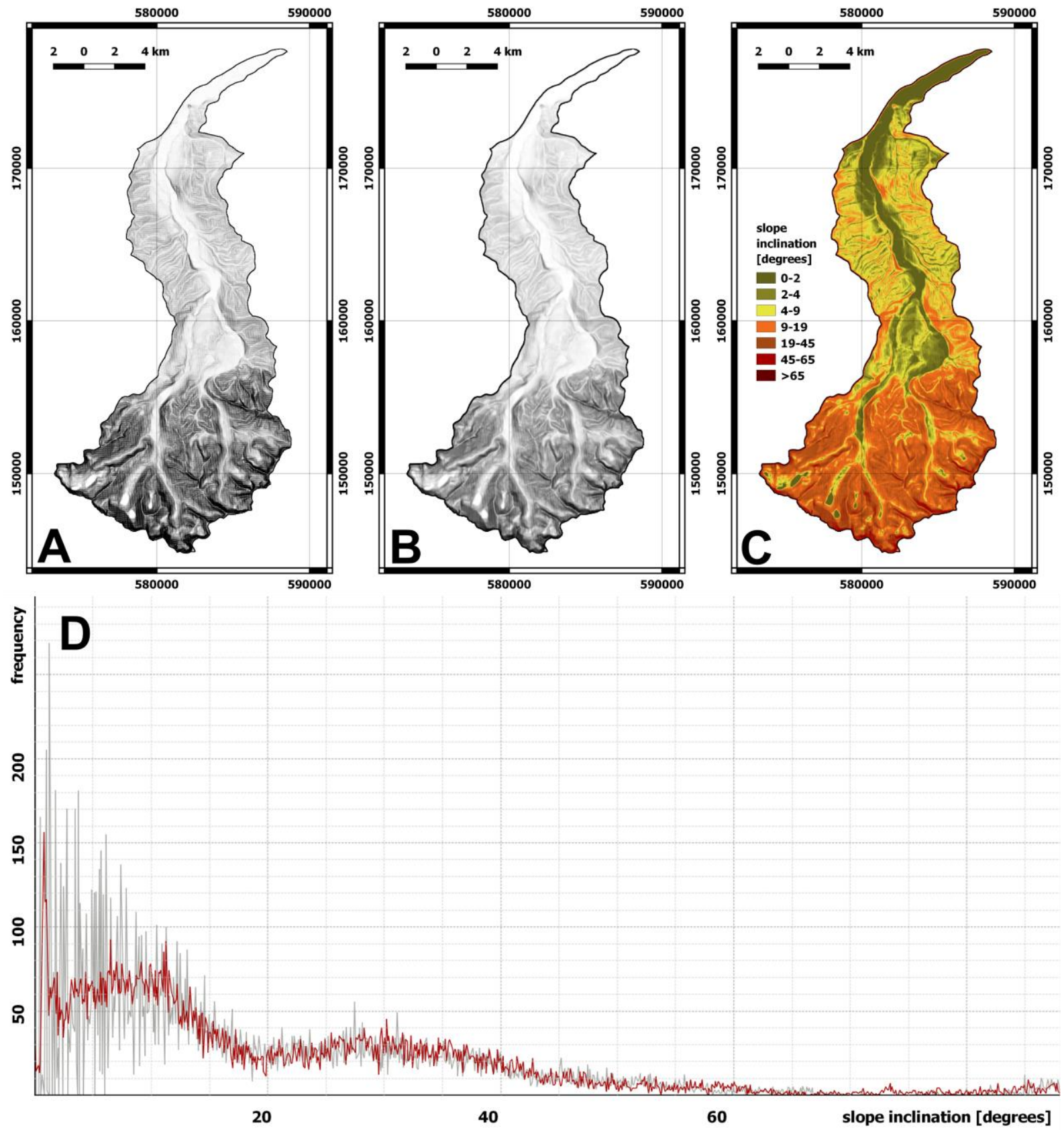
Fig.6. Slope inclination analysis A. Slope inclination map (based on DTED 2); B. Slope inclination filtered image; C. Classified slope inclination map: $0^{\circ}-2^{\circ}$ - plains; $2^{\circ}-4^{\circ}=$ slightly inclined slopes; $4^{\circ}-9^{\circ}=$ moderately inclined slopes; $9^{\circ}-19^{\circ}=$ strongly inclined slopes; $19^{\circ}-45^{\circ}=$ steep slopes; $45^{\circ}-65^{\circ}=$ very steep slopes; $>65^{\circ}=$ crags (Klimaszewski, 1963, 1978) ; D. Slope inclination histogram: grey line - raw data; red line - filtered data.

Aspect

A slope aspect map was also developed using the Aspect tool (Fig.7A). The raster was filtered (Fig.7B) with the simple filter which allowed to reduce of systematic errors, which are shown as peaks in the histogram at factors of $45^{\circ}$ azimuth
(Fig.7F). The systematic errors are caused by the numerical derivation over a rectangular grid. The differences are visible in the histograms as well as in the slope rose diagrams (Figs 7C and 7D). All statistical analyses were performed for slopes with an inclination of more than $2^{\circ}$, so the plains have been excluded.
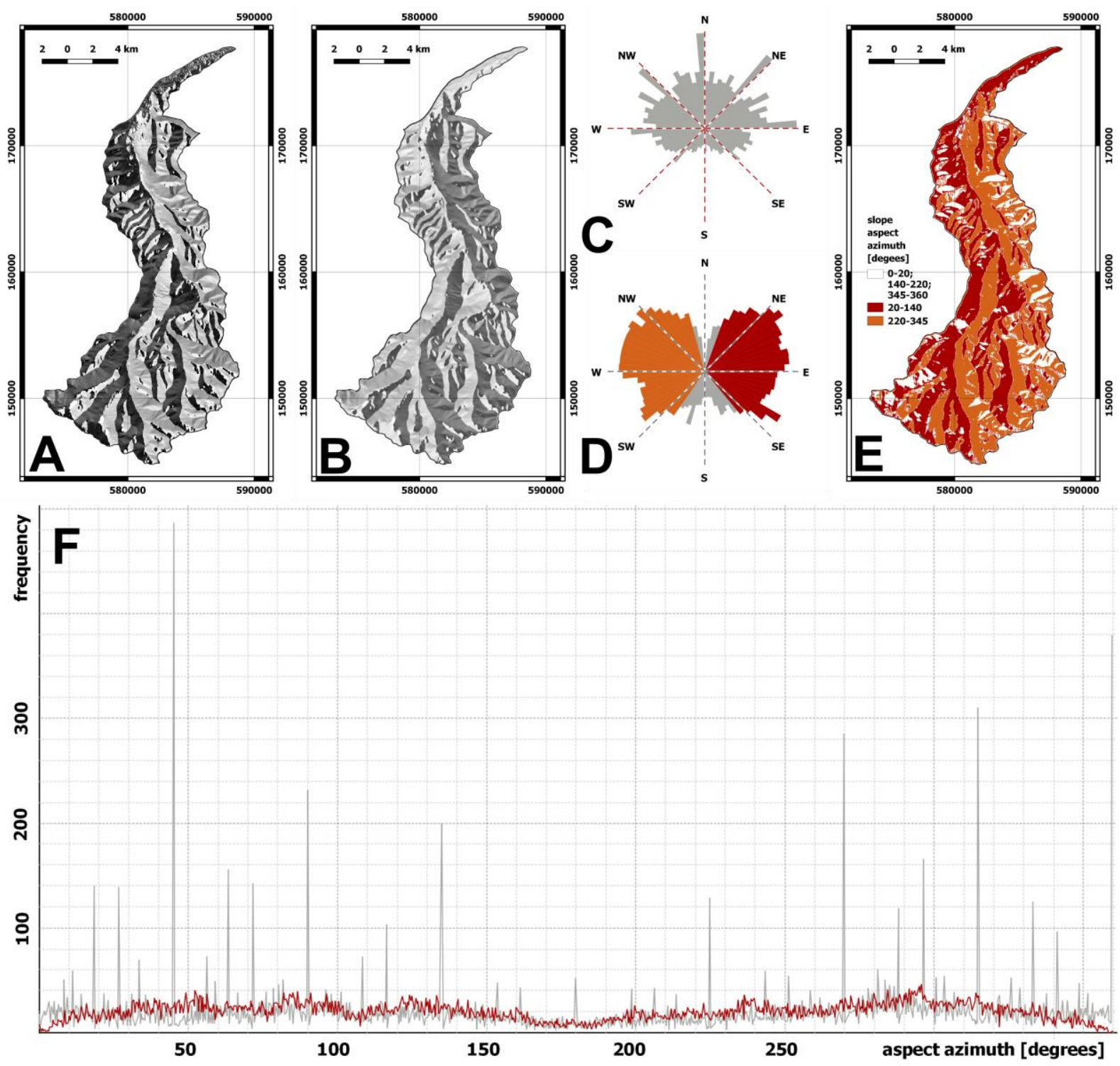

Fig.7. Slope aspect analysis A. Slope aspect map (based on DTED 2); B. Slope aspect filtered image; C. Slope aspect raw data rose diagram; D. Slope aspect filtered data rose diagram; E. Classified slope aspect map; F. Slope aspect histogram: grey line - raw data; red line - filtered data. 


\section{Lineaments}

Lineament analysis was carried out based on the classified map of the slope aspect (Figs 8A and $8 \mathrm{~B})$. This method of lineament extraction allows for the marking of the morphological
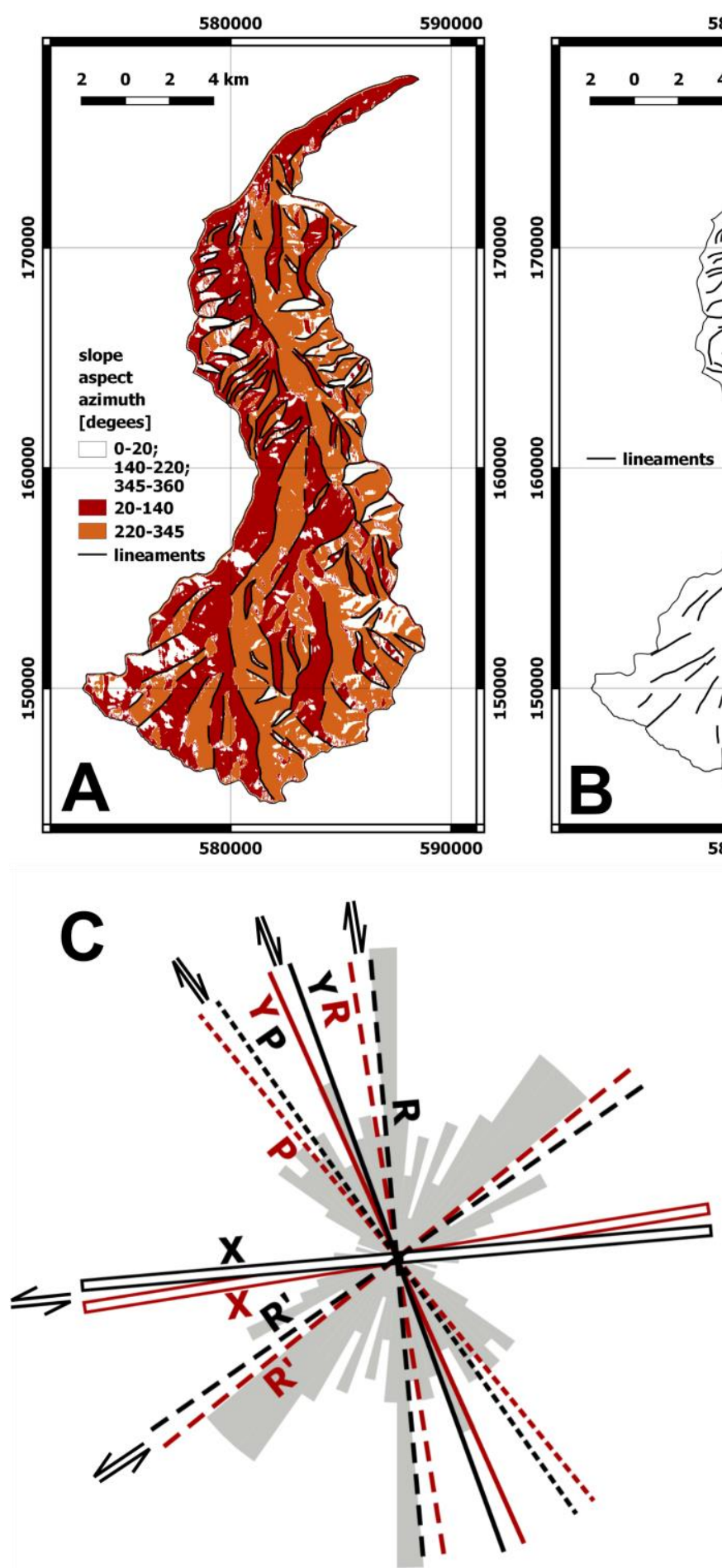

edges precisely (Jordan, 2003). The orientation diagram was then constructed. This allowed for the comparison of the geometry of the morphological and geological features (Fig.8C).

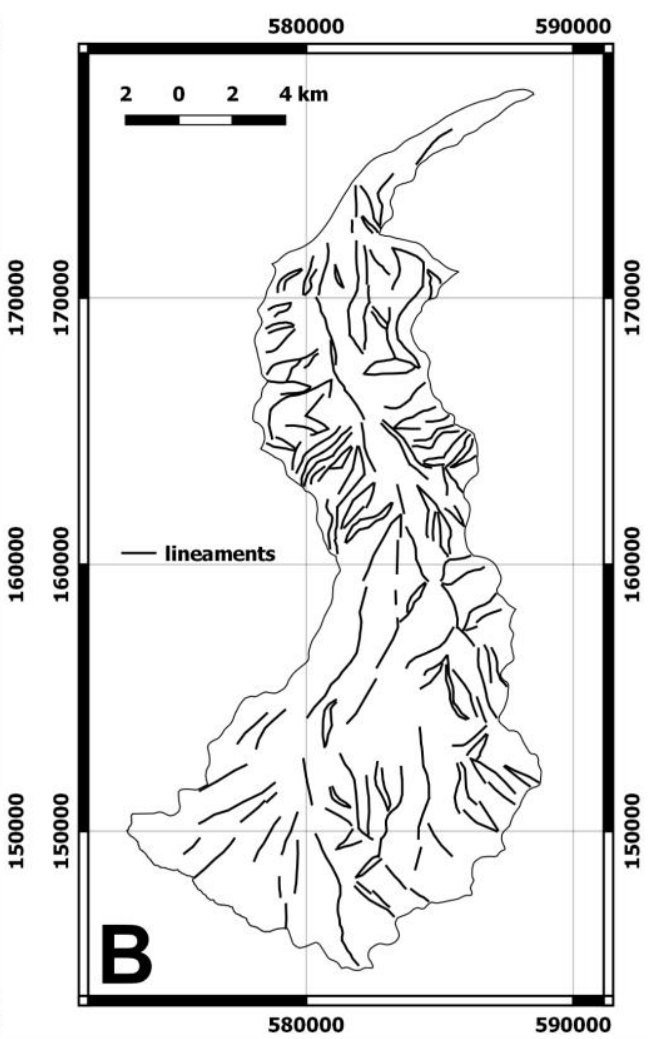

Białka fault

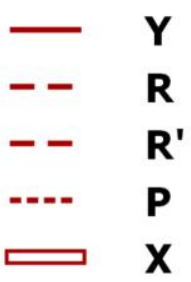

B. Dunajec fault

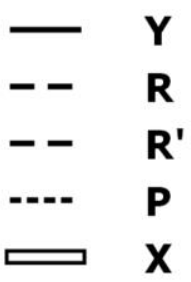


Fig.8. Lineament analysis. A. lineaments extracted from classified aspect map; B. lineament network map; C. lineament rose diagram overlaid by theoretical right-lateral simple shear models of the Białka and Biały Dunajec fault zones: Y - main fault; R - Riedel synthetic shears; R' Riedel - antithetic shears; P - secondary synthetic shears; $\mathrm{X}$ - complementary antithetic shears.

\section{Base Levels}

The concept of base-level was first defined by Powell in 1875 as a level below which the dry lands cannot be eroded. The ultimate base level is the level of the sea, however, local base levels can be defined according to different geological conditions across regions.

Base-level maps express the relationship between the valley order and topography (e.g. Zuchiewicz, 1981; Rączkowski et al, 1984). The valley order refers to the relative position of the stream segments within the drainage basin network, where streams of similar orders are related to similar geological events and are of similar geological age. Each base-level surface is related to a certain erosional stage, and can be considered as products of erosionaltectonic events, especially the most recent ones. The base-level map can also be seen as a "simplified" version of the original topographic surface, from which the "noise" of the loworder stream erosion has been removed (Zuchiewicz, 1981).

The construction of base-level maps (Fig.9) start from the initial map of valley orders, and are divided according to the Horton-Strahler method (Fig.4C). The drainage system of the Białka drainage basin was digitized from the Hydrographical Map of Poland (IMGW, 2007; Fig.4A) and cross-checked with the digital terrain model (Fig.4B). The rivers were then classified. Next, it was necessary to find the points where particular valley axes are crossed by contours of the same value (Fig.4C). It was then necessary to interpolate them with the smooth curves to create the isobases (Fig.8). The order of the base-level is determined by the order of valleys marked on the initial map. On the base level map of the 2nd order all valleys, except that of the 1st order, are to be drawn (Figs 10A and 10E). In the map of the 3rd order all valleys, except those of the 1 st and the 2 nd, have to be marked, (Figs 10B and 10F) etc.

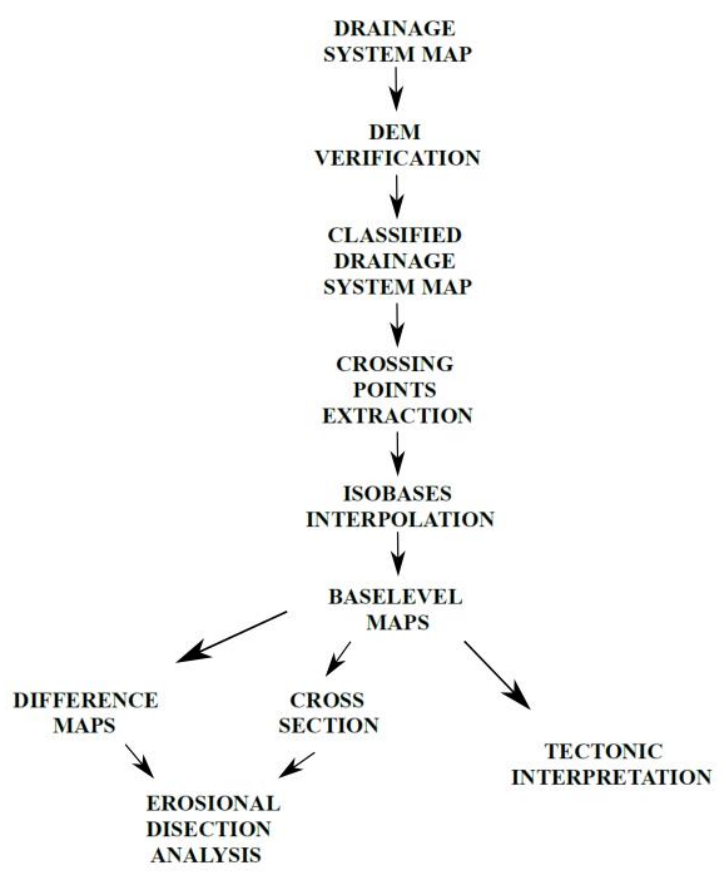

Fig.9. Base-level method scheme.

A series of base level maps makes it possible to construct a set of maps of differences among surfaces of various orders, as well as certain base-levels and the terrain surface (Figs 11A, 11B and 11C). Such maps inform us about the size of the erosional dissection (Figs 11D and $11 \mathrm{~F}$ ) of a given area during the period between the formation of the base-level surfaces.

\section{Isolongs Method}

Isolong maps provide the possibility of quantitatively estimating the relationship between tectonics and the valley order's growth, as it consists of the isolines of the valley lengths (Zuchiewicz, 2010). The length values of the certain stream segments have to be related to the centers of the measured sections and 

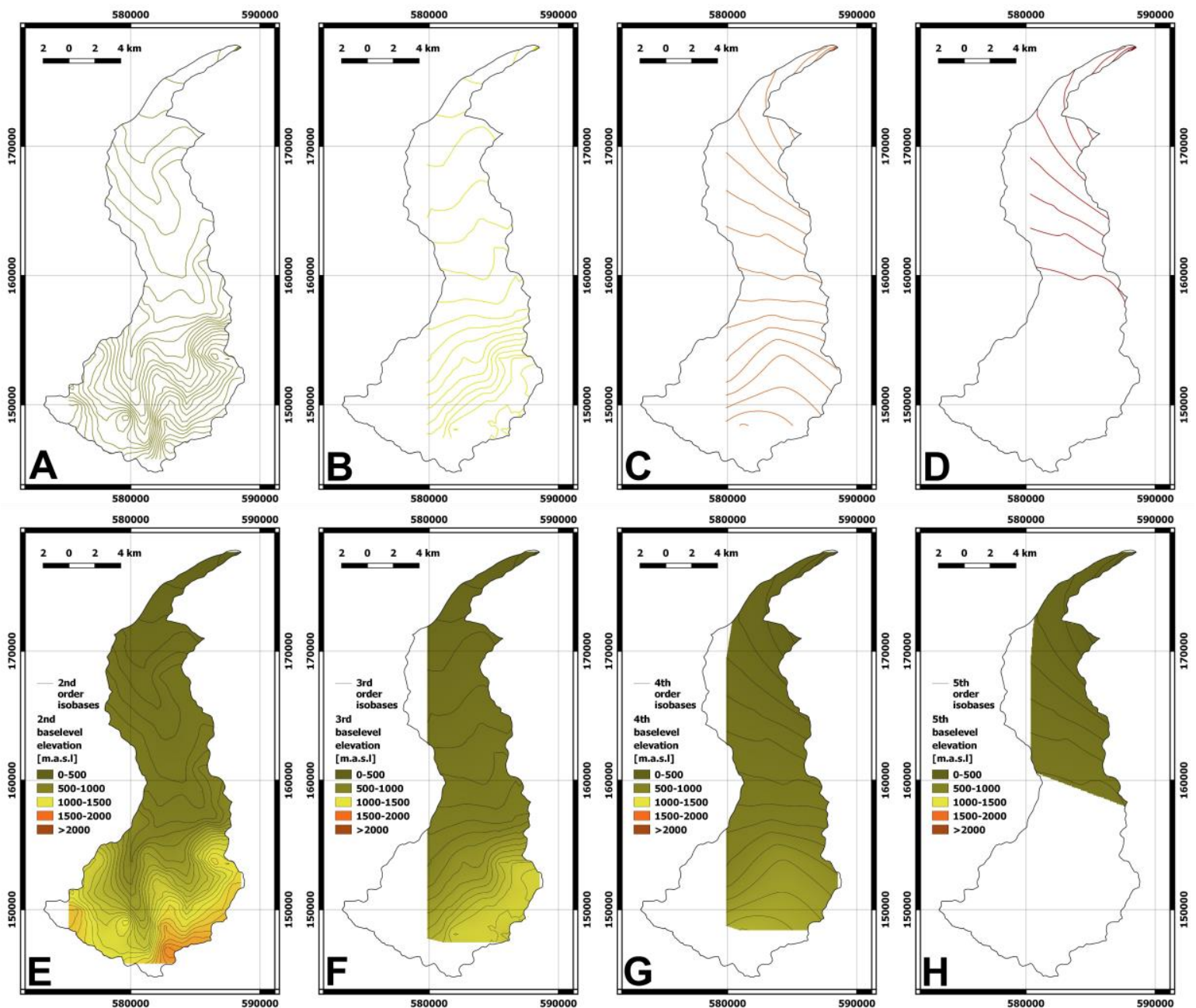

Fig.10. Base-level maps: A. 2nd order isobase map; B. 3rd order isobase map; C. 4th order isobase map; D. 5th order isobase map; E. 2nd order base-level map; F. 3rd order base-level map; G. 4th order base-level map; H. 5th order base-level map.

interpolated with the smooth curves (Figs 12 and 13). The highest values of valley lengths are usually connected with the narrow tectonic basins but the lowest ones characterize the uplifted areas. The isolong pattern should reflect mainly the buried uplifted areas. The degree of correlation between the tectonic maps and isolongs maps reaches a value of $85 \%$ (Zuchiewicz, 2010).

\section{Results}

\section{Drainage Basin Morphometry}

The results of the morphometric analysis of the drainage basins, performed previously for the area of Pieniny Seismic Region (Wołosiewicz and Chybiorz, 2015), indicate that the Białka drainage basin is one of the most tectonically active areas within the researched area (Fig.14). Two coefficients (Circulatory ratio - Rk; and Form ratio - Rf) suggest it to be tectonically active and two others suggest it to be moderately active (Elongation Ratio - Re; and Lemniscate Ratio - k; Tabs 1 and 3).

\section{Elevation}

The elevations in the study area range from $588 \mathrm{~m}$ a.s.1. to $2210 \mathrm{~m}$ a.s.1., at $2-98 \%$ cut-off level. The average elevation is $1207 \mathrm{~m}$ a.s.l., while the standard deviation is $445 \mathrm{~m}$. Values up to $1000 \mathrm{~m}$ a.s.l. are observed within the major part of the Białka drainage basin, including the 
Orava Basin and the Podhale region, as well as the valley floors of the major rivers within the
Tatra Mts. area. The higher values, up to 2210 $\mathrm{m}$ a.s.l., are related to the Tatra Mts. range.
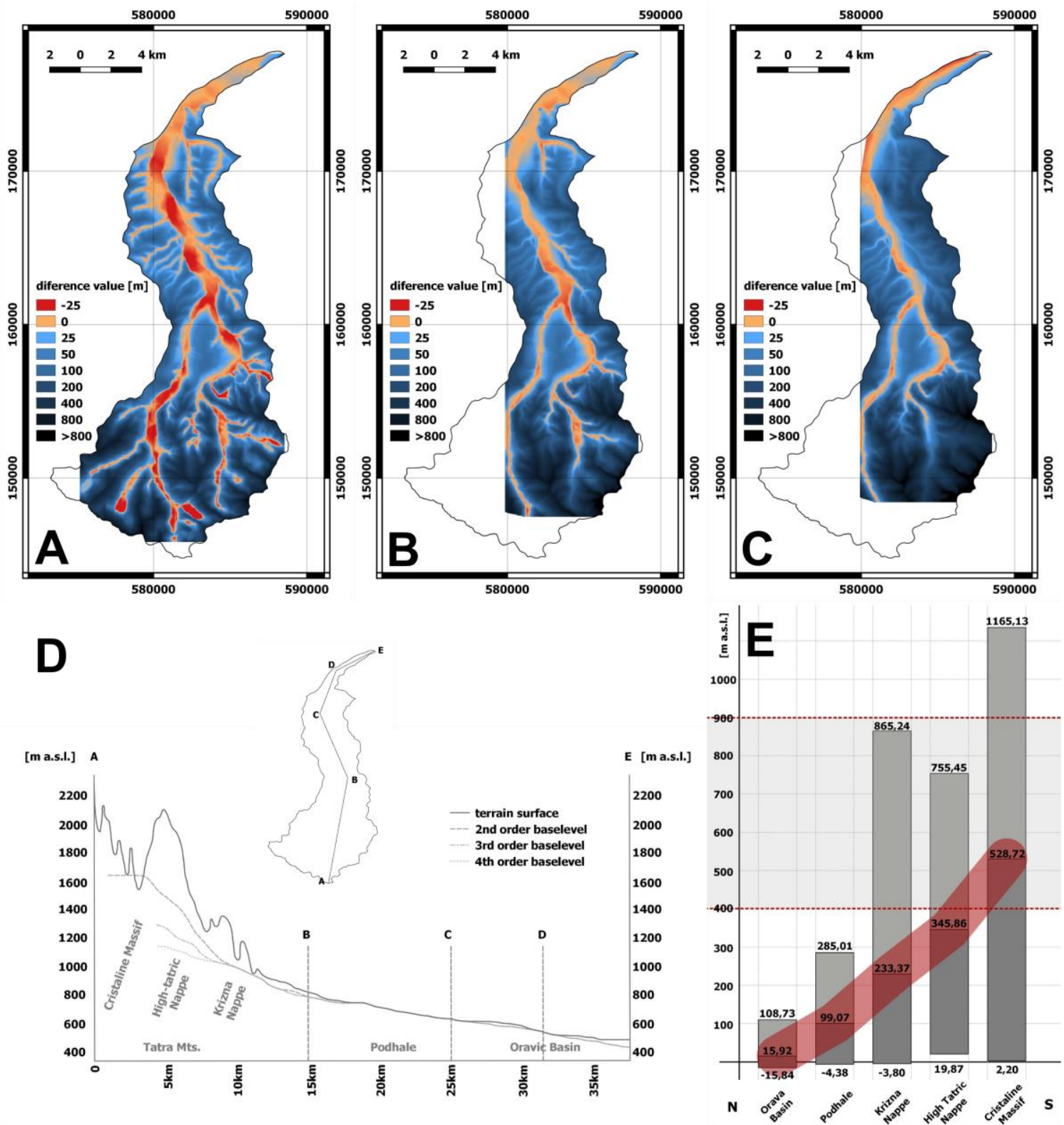

Fig.11. Base-level difference maps: A. 2nd order base-level and terrain surface difference map; B. 3rd order baselevel and terrain surface difference map; C. 4th order base-level and terrain surface difference map ; D. base-levels and terrain surfaces profile; E. Diagram of erosional dissection size between the terrain surface and 4th order baselevel. The diagram presents highest, lowest and mean values (reddish area). Grey area refers to the values calculated for the Tatra Mts. according to Zuchiewicz (1981).

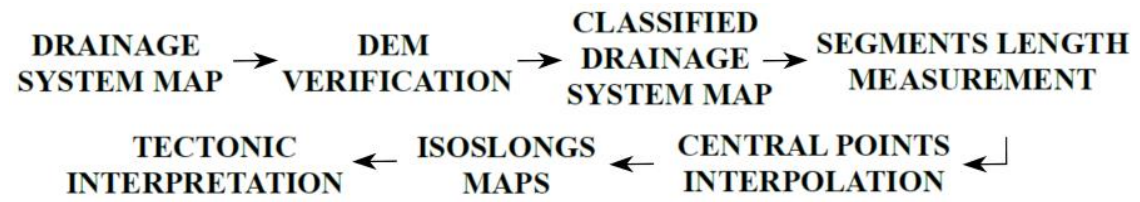

Fig.12. Isolong method scheme. 

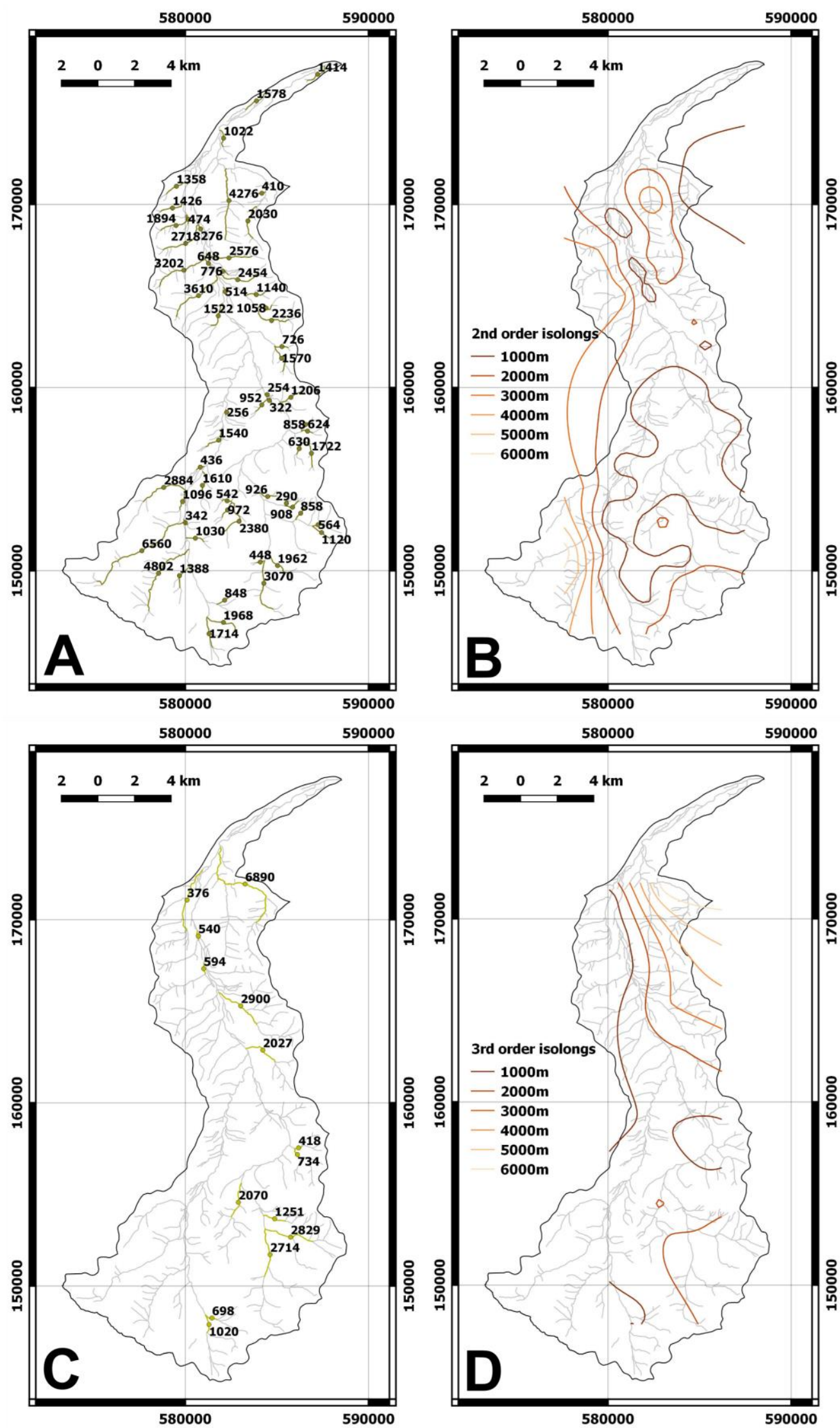

Fig.13. Isolong maps. A. 2nd order river length value map; B. 2nd order isolong map; C. 3rd order rivers length map; D. 3rd order isolongs map. 
Tab.3. Tectonic activity classes in the light of selected morphometric parameters (Wołosiewicz and Chybiorz, 2015).

\begin{tabular}{|c|c|c|c|c|c|}
\hline & Parameter & $\mathrm{Re}$ & $\mathrm{Rk}$ & $\mathrm{Rf}$ & $\mathrm{k}$ \\
\hline & References & $\begin{array}{l}\text { Bull and } \\
\text { McFadden } \\
\text { (1977) after } \\
\text { Schumm } \\
(1954) \\
\end{array}$ & $\begin{array}{c}\text { Brzezińska- } \\
\text { Wójcik } \\
\text { et al. (2010) after } \\
\text { Miller (1953) }\end{array}$ & $\begin{array}{c}\text { Brzezińska- } \\
\text { Wójcik } \\
\text { et al. (2010) after } \\
\text { Horton (1945) }\end{array}$ & $\begin{array}{l}\text { Brzezińska- } \\
\text { Wójcik } \\
\text { et al. (2010) after } \\
\text { Chorley (1971) }\end{array}$ \\
\hline $\begin{array}{l}0 \\
\tilde{W} \\
\tilde{\Xi} \\
\frac{\pi}{0}\end{array}$ & $\begin{array}{l}\text { 1. tectonically } \\
\text { active }\end{array}$ & $0.00-0.50$ & $0.00-0.50$ & $0.00-0.25$ & $>3$ \\
\hline 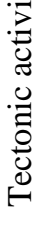 & $\begin{array}{l}\text { 2. moderately } \\
\text { active } \\
\text { 3. slightly active } \\
\text { (inactive) }\end{array}$ & $0.75-1.00$ & $0.75-1.00$ & $0.25-0.50$ & $2-3$ \\
\hline
\end{tabular}

\section{Slope Inclination}

Within the research area, plains can only be observed in its northern part in the Orava Basin as well as at the valley floors of the major rivers - especially the Białka River and Jaworowy Potok. Slightly inclined slopes are characteristic for the Podhale region, while more inclined ones are typical for the Tatra Mts. area. The most inclined crags are related to the highest ridges (Fig.6).

\section{Aspect}

According to the slope aspect rose diagram (Fig.7D) two classes have been defined: slopes inclined toward the East $\left(20-140^{\circ}\right)$ and slopes inclined toward the West $\left(215-345^{\circ}\right)$. Both classes consist of the $5^{\circ}$ bins that are represented by more than $1 \%$ of data. The symmetric form diagram with meridional separation suggests that they are representative of the opposite slopes, parallel to the main, $\mathrm{N}$ oriented streams. The division has been presented on the classified aspect map (Fig.7E).

\section{Lineaments}

Based on the classified aspect map, lines have been drawn to highlight the edges of hill slopes
(Fig.8A). The received lineaments network (Fig.8B) was analyzed on a rose diagram and compared with the theoretical right-lateral simple shear models developed for the Białka and Biały Dunajec fault zones (Fig.8C).

\section{Base-levels Analysis}

Within the Białka Drainage Basin the density of the isobases of all orders rises suddenly along the northern border of the Tatra Mts., the so called Zlin-Plavec lineament. High concentrations of isobases also exist along the deep fault zones of the Białka and Biały Dunajec. The area within the Tatra Mts. is characterized by highly concentrated archshaped isobases, while the Podhale region is characterized by less concentrated, parallel isobases.

The differences between the terrain surface and the base-levels, as well as between the baselevels of different orders, were also calculated (Fig.11). In particular, the differences between the terrain surface and the 4th order base-level surface (Early Quaternary; Zuchiewicz, 1981) were studied (Fig.11C). These values indicate relative tectonic tendencies. The size of the dissection is presented in Tab. 4 as well as in Figs 11D and 11E. 
Tab.4. Size of the erosional dissection calculated for the 4th base-level surface.

\begin{tabular}{cccc}
\hline \multirow{2}{*}{ Region } & \multicolumn{3}{c}{ dissection size [m] } \\
& $\min$ & $\max$ & mean \\
\hline Orava Basin & -15.84 & 108.73 & 15.92 \\
Podhale & -4.38 & 285.01 & 99.07 \\
Tatra Mountains & -3.80 & 1165.13 & 341.56 \\
Krizna Nappe & -3.80 & 865.24 & 233.37 \\
High Tatric Nappe & 19.87 & 755.45 & 345.86 \\
Crystalline Core & 2.20 & 1165.13 & 528.72 \\
\hline
\end{tabular}

\section{Isolong map analysis}

On both 2nd and 3rd order isolong maps, the values reach up to $6000 \mathrm{~m}$. The isoline orientation is mostly meridional and parallel to the main fault structures within the Białka watershed (Fig.15).

\section{Discussion and interpretation}

Morphometric studies of drainage basins performed by Wołosiewicz and Chybiorz (2015) allowed for the characterization of zones of relatively high tectonic activity (Fig.14). The distribution of these zones relates to the significant faults (e.g. Lipnica - Sylec fault, Prošecno-Lepietnica fault; Fig.3; Fusan et al., 1967), as well as the main watercourses. The zone based on the Białka River drainage basin supports the confirmation of the existence of the active Białka deep fault zone presented by Jurewicz (2005).

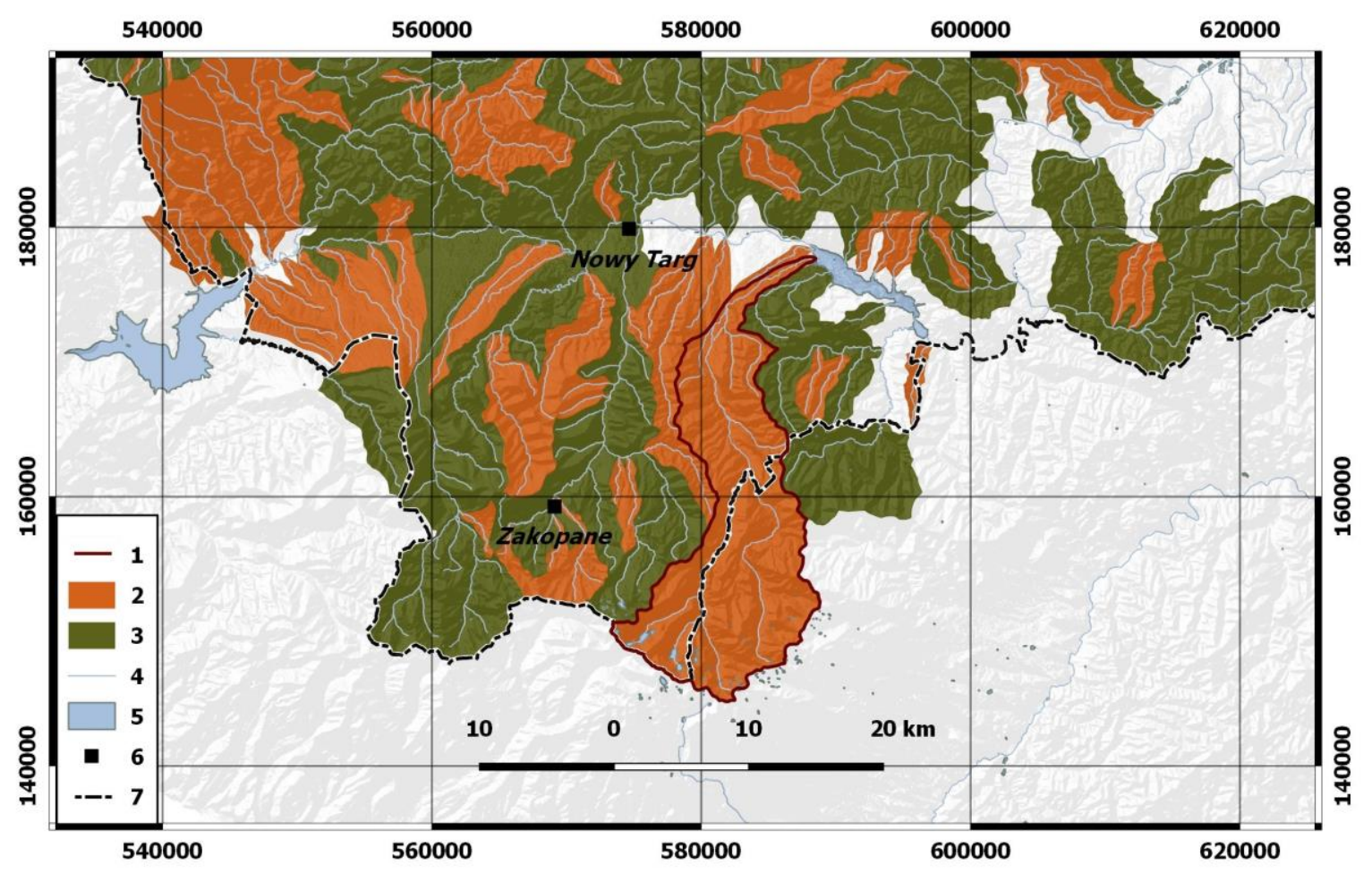

Fig.14. Tectonically active areas within the Pieniny Seismic Region, according to Wołosiewicz and Chybiorz (2015): 1. Białka drainage basin, 2. Relatively active areas according to the morphometric analysis of the drainage basins; 3. range of morphometric studies; 4. lakes; 5. rivers; 6. cities; 7. state boundary. 

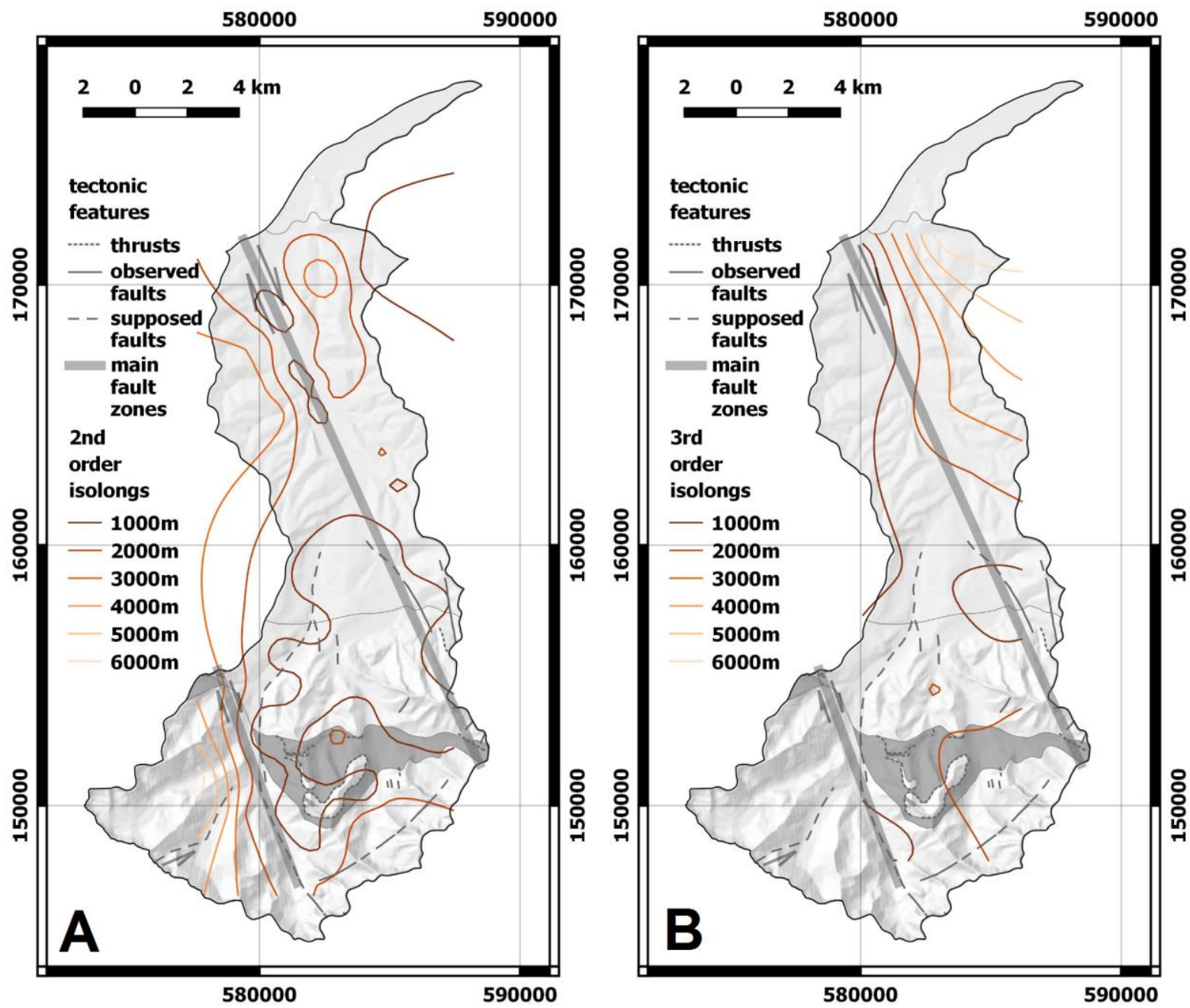

Fig.15. Tectonic interpretation of the isolong analysis. A - 2nd order isolongs map; B - 3rd order isolongs map.

The elevation and slope inclination maps are a basic reflection of the diverse morphology of the research area. They show the relationship between the landforms and the inner geological architecture, both the tectonic and lithological features. Specific thresholds visible on both maps reflect the borders between the major tectonic units such as the Tatra Mts, the Podhale synclinorium and the Orava Basin. The analysis of the lineament network developed from the classified aspect map confirms the geometric and possibly genetic relationship between those structures and the tectonic architecture of the research area. Their orientation reflects the main tectonic trends of the faults and fractures, especially the Białka and Biały Dunajec right lateral faults. The majority of the lineaments conform to the N-S oriented Riedel synthetic shears (R), and the NE-SW oriented Riedel antithetic shears (R'; e.g. Rybi Potok Dislocation; Jurewicz, 2002). The rose diagram also shows two minor sub-maxima of lineaments parallel to the main NNW-SSE oriented faults (Y; Jurewicz, 2005) and the secondary synthetic NW-SE trending shears (P). Previous lineament studies (e.g. W. Ozimkowski, 2002; 2008) were performed for larger area at a less accurate scale. NE-SW features such as the lineament of the Ružbachy fault, are visible on the maps, and corresponds to the results in this paper (Fig.8). Some of the sub-longitudinal structures are related to the major latitudinal Carpathian thrusts and leftlateral faults (Ozimkowski, 2002). 
Lineament extraction from the shaded relief (Ozimkowski, 2002; 2008) maps might cause some errors, because it is highly influenced by the sun azimuth and angle. Features perpendicular to the sun direction are more visible than others. This method requires using several variously lit shaded relief maps to achieve reliable results (multi-coverage). Aspect maps, on the other hand allow for the delineation of the valley and ridges precisely (Jordan, 2003).

The concentration of the isolines on the base-level maps should be related to the tectonically active areas, as the fault development can have a significant impact on the surface relief. However, the unexpected concentration of isolines along the northern border of the Tatra Mts. should not be considered a significant result because of the lithological differences between the Tatra Mts. area and the Podhale region (Żelaźniewicz et al., 2011). On the other hand, high concentrations of isolines along the main fault zones within the Tatra Mts. area further support the thesis.

The arch-shaped, highly concentrated isobases that can be observed in the Tatra Mts. area are typical for the folded zones (Zuchiewicz, 1981). This relationship reflects the architecture of the Mesozoic nappes of the Tatras (Jurewicz, 2005). The less concentrated, parallel isolines that occur in the northern part of the Białka watershed are a characteristic feature of the more monocline architecture. Despite, the flysch rocks are highly folded here (Mastella, 1975), the shape of the isolines is likely a reflection of the bigger regional structure, the Podhale synclinorium (Żelaźniewicz et al. 2011), which is probably a result of the accuracy of the research analysis performed at this scale.

The values of the erosional dissection calculated for the early Quaternary 4th baselevel increase towards South. The most rapid rise can be observed at the northern border of the Tatra Mts., which has been probably caused by their relative uplift (Jurewicz, 2005). The presence of negative values in the northern part of the research area can be considered a reflection of the opposite trend. The results correspond to the analysis of precise leveling data (Wyrzykowski, 1971; 1985; Makowska and Jaroszewski, 1987; Kowalczyk and Bednarczyk, 2009), as well as InSAR analysis (Perski, 2008). According to Makowska and Jaroszewski (1987) the present vertical dynamics of the Tatra Mts. and Podhale Region is expressed in the uplift of the Tatra Mts. relative to the Podhale zone, as well as the uplift of the whole area. The rate of the uplift in the Polish Carpathians varies from $0.001 \mathrm{~mm}$ per year in the outer Carpathians to $0.105 \mathrm{~mm}$ per year in the Tatra Mts. (Zuchiewicz, 1999). According to Makowska and Jaroszewski (1987) the rate of the uplift can reach up to 0.4 mm per year in the Tatra Mts.

It is worth considering that the calculated values are different than the data provided by Zuchiewicz (1981). This could be caused by the different scale of the model, as well as higher resolution and more precise, raster data used for the present study. For example, the results for the Tatra Mts. area, similar to those by Zuchiewicz (1981), can be achieved by filtering out $30 \%$ of the lowest values and $10 \%$ of the highest values. For this study only $2 \%$ of the lowest values and $2 \%$ of the highest values were eliminated to reduce random systematic errors. However, despite the differences, the general trends in both studies are similar.

The isolongs of the 2nd and 3rd order are NNW-SSE and N-S oriented and they correspond to the main tectonic features within the research area. The lowest values, reflecting the uplifted areas (Zuchiewicz, 1981), are concentrated along the main faults and especially along the axis related to the deep fault zones of the Białka and Biały Dunajec.

All calculations and analysis as well as the previously performed studies (Wołosiewicz and Chybiorz, 2015) confirm the asymmetric uplift of the Inner Carpathians, with the highest rate 
within the Tatra Mts. and slower rates towards the North. The neotectonic activity of the Carpathians has manifested itself as diverse erosional dissection along the Białka river valley (Fig.11; Baumgart-Kotarba, 1983).

\section{Conclusions}

\section{Geological and morphological findings}

- The results of morphometric analysis of the drainage basins as well as DEM based analysis support the idea that the foundation of the Białka river valley is related to the major fault zone known as the Białka fault. It has a significant influence on the morphology of the Białka watershed.

- According to the results of the lineament analysis, the buried structures of the Białka deep fault zone are reflected within the overlying rocks.

- The landforms represented by the lineament pattern reflect the inner geological architecture of the area, including the major trends of the fault related shears. The directions related to the N-S oriented Riedel synthetic shears (R), and the NE-SW oriented Riedel antithetic shears ( $\left.\mathrm{R}^{\prime}\right)$ are best represented.

- Base-level analysis supports the thesis regarding the relative uplifting tendencies of the Tatra Mts. and the opposite trend within the Podhale Region.

\section{Methodical remarks}

- All presented methods allow for examination of the general tectonic conditions within the research area. The methods are useful as an initial and complementary tool for analysis of the buried fault structures within areas where no direct data is available. This is especially true for the orientation of the isolongs; when parallel to the main structural trends they demonstrate that this method as a good indicator of the deep tectonic features.

- The main disadvantage of the method is the uncertainty of the precision of the results and also it depends on many nongeological factors.

- The results of morphometric studies depend on the resolution of the input data and the precision of the performed analysis. For more objective results the analysis should be performed at different scales.

- Morphometric analyses can be easily carried out and they are not as expensive as the geophysical and geological methods. The great variety of the morphometric coefficients allows to use them simultaneously, which makes the results more objective.

- Morphometric methods can be used as the initial analysis or as an analysis complementary to geological, geophysical or geodetic research.

- The results of both base-level and isolong methods primarily reflect the major, regional features and should be used for more extensive research areas.

\section{Acknowledgments}

I would like to thank the reviewers and editors for the constructive criticism and all useful suggestions. I would like to thank Jacek Szczygieł and Prof. Jerzy Żaba for help and support during development of this paper.

\section{References}

Bac-Moszaszwili, M., Burchart, J., Głazek, J., Iwanow, A., Jaroszewski, W., Kotański, Z., Lefeld, J., Mastella, L., Ozimkowski, W., Roniewicz, P., Skupiński, A., Westfalewicz-Mogilska, E. (1979) Geological map of the Polish Tatra Mts., 
1:30,000 scale (in Polish). Instytut Geologiczny, Warszawa.

Baumgart-Kotarba, M. (1983) Channel and terrace formation due to differential tectonic movements (with the eastern Podhale basin as example). Geographical Studies IG PAN vol. 145.

Badura, J., Zuchiewicz, W., Štěpančiková, P., Przybylski, B., Kotny, B., Cacoń, S. (2007) The Sudetic Marginal Fault: a young morphotectonic feature at the NE margin of the Bohemian Massif, Central Europe. Acta Geodynamica et Geomaterialia., 4, 4: 7-29.

Brzezińska-Wójcik, T., Chabudziński, Ł., Gawrysiak, L. (2010) Neotectonic mobility of the Roztocze region, Ukrainian part, Central Europe: insights from morphometric studies. Annales Societatis Geologorum Poloniae, 80: 167-183.

Bull, W.B. (1977) Tectonic geomorphology of the Mojave Desert. U.S. Geological Survey Contract Report 14-08-001-G-394. Office of Earthquakes, Volcanoes and Engineering, Menlo Park, California, 188 pp.

Bull, W.B. (1978) Geomorphic tectonic activity classes of the south front of the San Gabriel Mountains, California. U.S. Geological Survey Contract Report 14-08-001-G-394. Office of Earthquakes, Volcanoes and Engineering, Menlo Park, California, 59 pp.

Bull, W.B. (2007) Tectonic Geomorphology of Mountains. A New Approach to Paleoseismology. Blackwell Publishing, Malden, MA, 316 pp.

Bull, W.B., McFadden, L.D. (1977) Tectonic geomorphology north and south of the Garlock fault, California. In: Doehring, D. O. (ed.), Geomorphology in Arid Regions. Proceedings of the 8th Annual Geomorphology Symposium. State University of New York at Binghampton, 9: 115-138.

Chorley, R. J. (1971) The drainage basin as a fundamental geomorphic unit. In: Chorley,
R. J. (ed.), Introduction to Physical Hydrology. Methuen, London: 37-59.

Eagleson, P.S. (1970) Dynamic Hydrology. McGraw-Hill Book Company, New York, 462 pp.

Fusan, O., Kodym, O., Matejka, A., Urbanek, L. (1967) Geological map of CSSR 1:500,000. (in Czech) Ustr. Ust. Geol., Praha.

Guterch, B. (2009) Seismicity in Poland in the light of historical records (in Polish with English summary). Przegląd Geologiczny, 57: 513-520.

Gregory, K.J., Walling, D.E. (1973) Drainage Basin Form and Process. A Geomorphological Approach. Edward Arnold. Ltd., London, 456 pp.

Hantke, R., Scheidegger, A.E. (1999) Tectonic predesign in geomorphology. Lecture Notes in Earth Sciences, 78: 251-266.

Horton, R.E. (1945) Erosional development of streams and their drainage basins; hydrophysical approach to quantitative morphology. GSA Buletin, 56: 275-370.

IMGW (2007) Digital map of hydrographic divide of Poland.

Jordan,G. (2003) Morphometric analysis and tectonic interpretation of digital terrain data: a case study. Earth Surface Processes Landforms 28, 807-822.

Jurewicz, E. (2002) Geometric analysis of steep-dipping dislocations within the granitoid core in the Polish part of the Tatra Mts. Annales Societatis Geologorum Poloniae, 72: 89-98.

Jurewicz, E. (2005) Geodynamic evolution of the Tatra Mts. and the Pieniny Klippen Belt (Western Carpathians): problems and comments. Acta Geologica Polonica, 55: 295-338.

Kawecka, A., Zając, J. (1989) Geological Map of the Western Outer Carpathians and their foreland without Quaternary formations. [In:] Geological Atlas of the Western Outer Carpathians and their Foreland (eds. D. Poprawa and J. Nemcok). Państwowy Instytut Geologiczny, Warszawa. 
Klimaszewski, M. (1963) Problems of Geomorphological Mapping. Geographical Studies. IG PAN vol. 46

Klimaszewski, M. (1978) Geomorphology (in Polish). PWN Warszawa.

Klimaszewski, M. (1988) Landforms of the Polish Tatra Mts (in Polish). PWN Warszawa.

Kowalczyk, K., Bednarczyk, M. (2009) Relational database of three precise leveling campaigns in Poland. Technical Sciences, 12: 145-164.

Książkiewicz, M. (1977) The Tectonics of the Carpathians. In: Geology of Poland, vol. 4. Tectonics. The Alpine Tectonic Epoch. Geological Institute, Warsaw: 476-608.

Lindner, L., Dzierżek, J., Marciniak, B., \& Nitychoruk, J. (2003). Outline of Quaternary glaciations in the Tatra Mts .: their development, age and limits. Geological Quarterly, 47, 3, 269-280.

Makowska, A., Jaroszewski, W. (1987) On present vertical movements in Tatra Mts and Podhale (in Polish with English summary). Przegląd Geologiczny, 35: 506511.

Marks L., Ber, A., Gogołek, W., Piotrowska, K. (2005) Geological map of Poland, 1:500000. PIG,

Warszawa.

Marshalko, R. (1970) The research of sedimentary textures, structures, and palaeocurrent analysis of basal formations (Central Western Carpathian Paleogene, N of Spišsko-gemerské rudohorie Mts.). Acta Geologica Geographica 19: 129-163.

Mastella, L. (1975) Flysch tectonics in the eastern part of the Podhale Basin (Carpathians, Poland). Annales Societatis Geologorum Poloniae 45: 361-401.

Miller, V. C. (1953) Quantitative geomorphological study of drainage basin characteristics in Clinch Mountain area, Tennessee. ONR Technical Report 3, Project No. 271-030. New York, Columbia University.
Ozimkowski, W. (2002) Carpathian lineaments in Poland. Przegląd Geologiczny, 50: 810. (in Polish)

Ozimkowski, W. (2008) Lineaments of Tatra Mts. surroundings - DEM vs. MSS. Przegląd Geologiczny, 56: 1099-1102. (in Polish)

Perski, Z. (2008) Recent tectonic activity of the Tatra Mts and Podhale (Poland) studied by InSAR and PSInSAR. Przegląd Geologiczny, 56: 1082-1086.

Pike, R.J. (2000) Geomorphometry - diversity in quantitative surface analysis. Progress in Physical Geography, 24: 1-20.

Pike, R.J. (2002) A bibliography of terrain modeling (geomorphometry), the quantitative representation of topography supplement 4.0. Open-File Report 02-465. U.S. Geological Survey, Denver.

Powell, J.W., (1875) Exploration of the Colorado River of the West. Washington, D.C., U.S. Government Printing Office, 291 pp.

Rączkowski, W., Wójcik, A., and Zuchiewicz, W. (1984) Late Neogene Quaternary tectonics of the Polish Carpathians in the light of neotectonic mapping: Tectonophysics, v. 108 (1-2): 51-69.

Rockwell, T. K., Keller, E. A. \& John son, D. L. (1984) Tectonic geomorphology of alluvial fans and mountain fronts near Ventura, Califor nia, In: Morisawa, M., Hack, T. J. (eds), Tectonic Geomorphology. Publications in Geomorphology. State University of New York, Binghamton: 183207.

Schumm, S.A. (1954) Evolution of drainage systems and slopes in badlands at Perth Amboy. New Jersey. GSA Bulletin, 69: 597-646.

Smith, K.G. (1950) Standards for grading texture of erosional topography. American Journal of Science, 248: 655-668.

Starkel, L. (1972) An outline of the relief of the Polish Carpathians and its importance for 
human management (in Polish with English summary). Problemy Zagospodarowania Ziem Górskich, 10: 75-150.

Wells, S. G., Bullard, T. F., Menges, T. M., Drake, P. G., Karas, P. A., Kelson, K. I., Ritter, J. B. \& Wesling, J. R. (1988) Regional variations in tectonic geomorphology along segmented convergent plate boundary, Pacific coast of Costa Rica. Geomorphology, 1: 239-265.

Wołosiewicz, B., Chybiorz, R. (2015) Application of the morphometric and remote sensing methods for studies on neotectonic activity of Pieniny Seismic Region. In: Conference materials: IV Conference GIS in science, Poznań 2015.

Wyrzykowski T. (1971) The map of absolute speed of recent vertical movements of the crust in Poland. Państwowe Przedsiębiorstwo Wydawnictw Kartograficznych, Warszawa.

Wyrzykowski T. (1985) The map of speed of recent vertical movements of the crust in Poland. Instytut Geodezji i Kartografii, Warszawa.
Zuchiewicz, W. (1981) Morphotectonic methods applied to the morphostructural analysis of mountainous topography (Polish Western Carpathians). Annales Societatis Geologorum Poloniae, 51 (1-2): 99-116, Kraków.

Zuchiewicz, W. (1999) Morphometric techniques as a tool in neotectonic studies of the Polish Carpathians (southern Poland) (in Polish with English summary). Przegląd Geologiczny, 47: 851-854.

Zuchiewicz, W. (2010) Neotectonics of Polish Carpathians and their foredeep (in Polish with English summary). Wydawnictwa AGH, Kraków.

Żaba, J. (1995) Strike-slip faults at the edge zone of Upper Silesia and Małopolska Blocks (Southern Poland). Przegląd Geologiczny, 43: 838-842.

Żelaźniewicz, A., Aleksandrowski, P., Buła, Z., Karnkowski, P. H., Konon, A., Ślączka, A., Żaba, J., Żytko, K. (2011) Tectonic regionalization of Poland (in Polish). Komitet Nauk Geologicznych PAN, Wrocław. 